Article

\title{
In Vitro Antifungal Efficacy of White Radish (Raphanus sativus L.) Root Extract and Application as a Natural Preservative in Sponge Cake
}

\author{
Huynh Hoang Duy ${ }^{1, *}$, Pham Thi Kim Ngoc ${ }^{1}$, Le Thi Hong Anh ${ }^{2}$, Dong Thi Anh Dao ${ }^{1, *}$, \\ Duy Chinh Nguyen ${ }^{3}(1)$ and Van Thai Than ${ }^{4}(\mathbb{B}$ \\ 1 Faculty of Chemical Engineering, HCMC University of Technology, Vietnam National University System \\ Hochiminhcity, 268 Ly Thuong Kiet St., District 10, Ho Chi Minh City 700000, Vietnam \\ 2 Faculty of Food Science and Technology, Ho Chi Minh City University of Food Industry, \\ 140 Le Trong Tan St. Ho Chi Minh City 700000, Vietnam \\ 3 NTT Hi-Tech Institute, Nguyen Tat Thanh University, Ho Chi Minh City 70000, Vietnam \\ 4 Center of Excellence for Biochemistry and Natural Products, Nguyen Tat Thanh University, \\ Ho Chi Minh City 700000, Vietnam \\ * Correspondence: huynhhoangduy90@gmail.com (H.H.D.); dtanhdao@hcmut.edu.vn (D.T.A.D.)
}

Received: 10 July 2019; Accepted: 6 August 2019; Published: 21 August 2019

\begin{abstract}
The study attempts the optimization of the total flavonoid content (TFC) and the 2,2'-azino-bis(3-ethylbenzothiazoline-6-sulphonic acid) (ABTS) antioxidant activity of the white radish (Raphanus sativus L.) root ethanolic extract (WRE) with regard to several parameters including ethanol concentration, the ratio of solvent/material, temperature and extraction time. Then antifungal analysis of WRE was performed against four fungal species including Aspergillus flavus NBRC 33021, Aspergillus niger NBRC 4066, Aspergillus clavatus NBRC 33020, and Fusarium solani NBRC 31094. At the WRE concentration of $75 \mathrm{mg} / \mathrm{mL}$, diameters of inhibition zone were $9.11 \pm 1.5,19.55 \pm 1.68$, $17.72 \pm 0.25$, and $17.50 \pm 0.73 \mathrm{~mm}$ respectively against the four examined species. Minimum fungal concentration (MFC) values of WRE against the four species were 30, 10, 20 and $30 \mathrm{mg} / \mathrm{mL}$ respectively. Evaluation of the sponge cake added with white radish root extract suggested that shelf-life of the sponge cake is 8 weeks in air-cooled condition $\left(20^{\circ} \mathrm{C}\right)$ and two weeks in warm condition $\left(37^{\circ} \mathrm{C}\right)$.
\end{abstract}

Keywords: Raphanus sativus L.; antifungal activity; shelf-life study; sponge cake

\section{Introduction}

Raphanus sativus L., commonly referred to as radish or daikon, is a cruciferous vegetable that belongs to the Brassicaceae family and finds a myriad of applications in the daily diet and traditional medicine of Eastern societies. The radish is one of the most consumed vegetables in Asian countries, including Vietnam, China and Japan, and is regarded as an important ingredient in the treatment of liver and respiratory diseases [1,2]. Biological activities of radish are diverse and have been ascertained in many investigations, which were well summarized in a past review [3]. In brief, the radish extract was shown to exhibit inhibitory effect on growth of $\mathrm{G}+, \mathrm{G}^{\prime \prime}$ bacteria, antifungal, immunological, antioxidant, anticancer and antiviral properties. The antibacterial activity is mostly due to the presence of cysteine-rich peptides (Rs-AFP1 and Rs-AFP2), RAP-1 and RAP-2 protein, cafeic, ferulic and phydroxybenzoic acid. In addition, it was found that four types of the glucosinolate compound, including glucoraphenin, dehydroerucin, glucobrassicin, and glucoerucin are responsible for the pungency of Raphanus satious, predominate in roots of radish [4]. Glucosinolate has been shown to take part in promoting enzymatic activities involving removal of carcinogens and preventing aging in the human body. 
Different parts of the radish plant show varying degrees of biological activities [5,6]. While seeds and aerial parts of Raphanus sativus have been long known for strong antifungal and antibacterial activity due to the presence of the raphanin compound, to date, current evidence has only documented moderate inhibitory effects of the Raphanus sativus root against various bacteria species only and thus, making data with regard to antifungal activities of Raphanus sativus uncomprehensive [7-10]. For example, in a previous in vitro study involving 52 selected food-borne bacteria species, methanol extracts from white skin Raphanus sativus roots were shown to inhibit the growth of 11 species (Arthrobacter atrocyaneus, Corynebacterium ammoniagenes, Enterobacter hormaechei, Kocuria rosea, Neisseria subflava, Pantoea agglomerans, Proteus vulgaris, Psychrobacter immobilis, Shigella dysenteriae, Bacillus sphaericus and Corynebacterium flavescens) [11]. This result was further extended in another similar study where growth-inhibitory effect of radish root juice was determined against five other microbial species including Klebsiella pneumoniae, Staphylococcus aureus, Pseudomonas aeruginosa, Enterococcus faecalis and Escherichia coli with minimum inhibitory concentrations (MIC) ranging from 0.078 to $0.625 \mathrm{mg} / \mathrm{mL}$ [12]. However, those reported antibacterial effects were not as high as those exhibited by standard drugs, which are respectively maxipime and ampicillin in the two studies.

Apart from the cysteine-rich peptides, the antibacterial activity of the taproot of Raphanus sativus might be attributed specifically to its content of flavonoids, which figure for various health-beneficial effects and strong antimicrobial properties [3]. The inhibition mechanism of flavonoids against microbial growth was implied in a review proposing that highly polar phenolic compounds, including flavonoids, tannins, and quinones, could bind to and thus interfering with the conformation of $A B C$ transporter proteins in pathogenic fungi and microbes $[13,14]$. In Indian Raphanus sativus roots, the total flavonoid content reached $43.5 \mathrm{mg} \mathrm{CE} / 100 \mathrm{~g}$ fresh mass, which was comparable to those found in Indian apples and ladyfinger fruits, respectively at 48.5 and $48.2 \mathrm{mg} \mathrm{CE} / 100 \mathrm{~g}$ fresh mass [15]. This was supported by results of another study where flavonoids and alkaloids were consistently found in Raphanus sativus root peel extracts regardless of employed solvent and extraction method [16]. In terms of flavonoid composition in Raphanus sativus root, it was revealed that radish root contains four major types of flavonoids including kaempferol, luteolin, quercetin and apigenin respectively at 32.3, 19.5, 5.2 and $2.2 \mathrm{mg} / \mathrm{kg}$ fresh weight [17].

It is a common extrapolation in previous antimicrobial and antioxidant assays that Raphanus sativus taproots could act as a promising ingredient for manufacture of bio-preservatives used in foods. However, to our knowledge, it is difficult to comprehend this justification in absence of relevant results on antifungal activity. In addition, to permit feasible production of health-safe additives, optimization of flavonoid content accruing from the extraction process of the radish root as well as preservability and palatability evaluation of food supplemented with radish-derived preservatives should be carried out. Therefore, the objective of in this study is three-fold. First, we optimize the total flavonoid content in the extracts of the Raphanus sativus roots with respect to different experimental parameters. Second, the antifungal activity against Aspergillus flavus NBRC 33021, Aspergillus niger NBRC 4066, Aspergillus clavatus NBRC 33020, and Fusarium solani NBRC 31094 fungi of the obtained Raphanus sativus taproot extracts will be determined via well diffusion assays. Third, to assess the suitability of the extracts in food applications, we evaluate preservability, sensory characteristics and several important microbial indicators of a sponge cake formula incorporated with the dried extract of the Raphanus sativus root. The results are expected to aid further development of natural preservatives derived from abundant and inexpensive plant materials.

\section{Materials and Methods}

\subsection{Materials}

\subsubsection{Plant Materials}

White radish roots were collected from the farming field of Tran Gia Company, a major vegetable provider situating in Dalat city, Lam Dong province, Vietnam. Obtained roots were of the first 
generation (F1) weighing around 200-300 g/root, having the diameter of $3.5 \pm 0.5 \mathrm{~mm}$ and length of $17.5 \pm 2.5 \mathrm{~cm}$. Materials were pretreated by washing under tap water and then sliced and dried at $50{ }^{\circ} \mathrm{C}$ to reach the final moisture level of $6-7 \%(\mathrm{w} / \mathrm{w})$. Subsequently, the dried slices of white radish were ground to a powder and sieved through a sifter ( $40 \mathrm{mesh})$. Finally, they were stored in sealed bag and kept in a freezer at $-20^{\circ} \mathrm{C}$.

\subsubsection{Ingredients for Sponge Cake}

Ingredients include fresh whole eggs (Ba Huan Joint-Stock Company, Ho Chi Minh City, Vietnam), medium flour (Interflour Group Pte Ltd., Ho Chi Minh City, Vietnam), powdered refined white sugar fine (Ninh Hoa Sugar Joint Stock Company, Khanh Hoa province, Vietnam), vegetable oil (Cargill Inc., Kuala Lumpur, Malaysia), sorbitol liquid (Roquette, Lestrem, France), cake-gel emulsifier (Rikevita, Johor, Malaysia), whole milk powder (Fonterra, Auckland, New Zealand), salt (Tan Thanh, Ho Chi Minh City, Vietnam), xanthan gum (ADM, Chicago, IL, USA).

\subsubsection{Culture Media and Microorganisms}

Sabouraud dextrose agar (SDA) was purchased from Himedia Laboratories, Mumbai India. Commercial antifungal agent of Natamycin was purchased from Handary (Uccle, Belgium).

The mold isolates of Aspergillus flavus NBRC 33021, Aspergillus niger NBRC 4066, Aspergillus clavatus NBRC 33020 and Fusarium solani NBRC 31094 were obtained from stock cultures of the Institute of Microbiology \& Biotechnology, Vietnam National University, Hanoi, Vietnam.

\subsubsection{Photocatalytic Degradation of Rhodamine B}

All chemicals and solvents were of analytical grade. The reagents used were Trolox (Sigma-Aldrich 23,881-3, St. Louis, MO, USA), (6-hydroxy-2,5,7,8-tetramethylchromane-2-carboxylic acid), was used as anti-oxidant. ABTS (Sigma-Aldrich, A1888, St. Louis, MO, USA)-2,2'-Azino-bis (3-Ethylbenzthiazoline-6-sulfonic acid) and potassium persulfate $\mathrm{K}_{2} \mathrm{~S}_{2} \mathrm{O}_{8}$ (Sigma-Aldrich, P5592, St. Louis, MO, USA) were used to prepare a solution containing the radical cation ABTS ${ }^{\bullet+}$. Gallic acid $\left(3,4,5\right.$, trihydroxybenzoic acid, $\left.\mathrm{C}_{6} \mathrm{H}_{2}(\mathrm{OH})_{3}-\mathrm{COOH}, \mathrm{MW}=170 / 12\right)$, quercetin $\left(\mathrm{C}_{15} \mathrm{H}_{10} \mathrm{O}_{7}\right)$, sodium bisulfite $\left(\mathrm{NaHSO}_{3}\right)$, and acetate $\left(\mathrm{CH}_{3} \mathrm{COOK}\right)$ were purchased from Sigma-Aldrich, St. Louis, $\mathrm{MO}$, USA.

\subsection{Method}

\subsubsection{Preparation of White Radish Extract (WRE)}

Figure 1 illustrated the preparation process of WRE. The root powder was extracted via solvent extraction method with ethanol $70 \%(v / v)$, ratio of substrate and ethanol: $1 / 20 \mathrm{~g} / \mathrm{mL}$ for $4 \mathrm{~h}$ at $60{ }^{\circ} \mathrm{C}$. After extraction, the mixture was filtered thrice through Whatman No.1 paper. The filtrate was evaporated under vacuum to a constant weight to obtain a crude, flavonoid-rich paste. Prior to spray drying, this crude paste was mixed with maltodextrin $4 \%$ (based on the dry matter). To obtain white radish root extract (WRE) with a moisture of lower than $6.0 \%(\mathrm{w} / \mathrm{w})$, the temperature for spray drying was maintained at $160{ }^{\circ} \mathrm{C}$. Finally, WRE were packed tightly in a thermoplastic low-density polyethylene bag and avoid direct light until further use.

\subsubsection{Preparation of Sponge Cake}

The sponge cake formula was produced by a standard all-in procedure, as illustrated in Figure 2 [18]. All ingredients were mixed in a mixer (Kenwood KM250, Kenwood Ltd., Woking, UK). For the control sample, $1300 \mathrm{ppm}$ of potassium sorbate was added. For the testing sample, this preservative was replaced by $30 \mathrm{mg} / \mathrm{mL}$ of WRE. After mixing, the dough was transferred to aeration machine to create a foam structured dough. The specific gravity of the obtained dough was approximately $0.47-0.49$ and the temperature was around $28-30{ }^{\circ} \mathrm{C}$. Prior to baking, the dough was transferred into tanks and was pumped into molds through forming nozzles. An automatic oven (Dong Yang Dynamics) with 
baking functionality was employed with setting profiles: $170{ }^{\circ} \mathrm{C}$ for $16 \mathrm{~min}$ for oven zone $1,190{ }^{\circ} \mathrm{C}$ for $5 \mathrm{~min}$ for oven zone $2 ; 220^{\circ} \mathrm{C}$ for $3 \mathrm{~min}$ for oven zone $3,1 \mathrm{~min}$ for damper, total baking time of $23 \mathrm{~min}$. The cake after cooling is injected with a custard cream with a weight of 8.0-8.5 g/piece. To preserve the product, each cake was sprayed with $0.3 \pm 0.05 \mathrm{mg}$ of alcohol solution $30 \%(v / v)$ onto their surfaces. Finally, the products were packed under tight conditions and prevented from exposure to air.

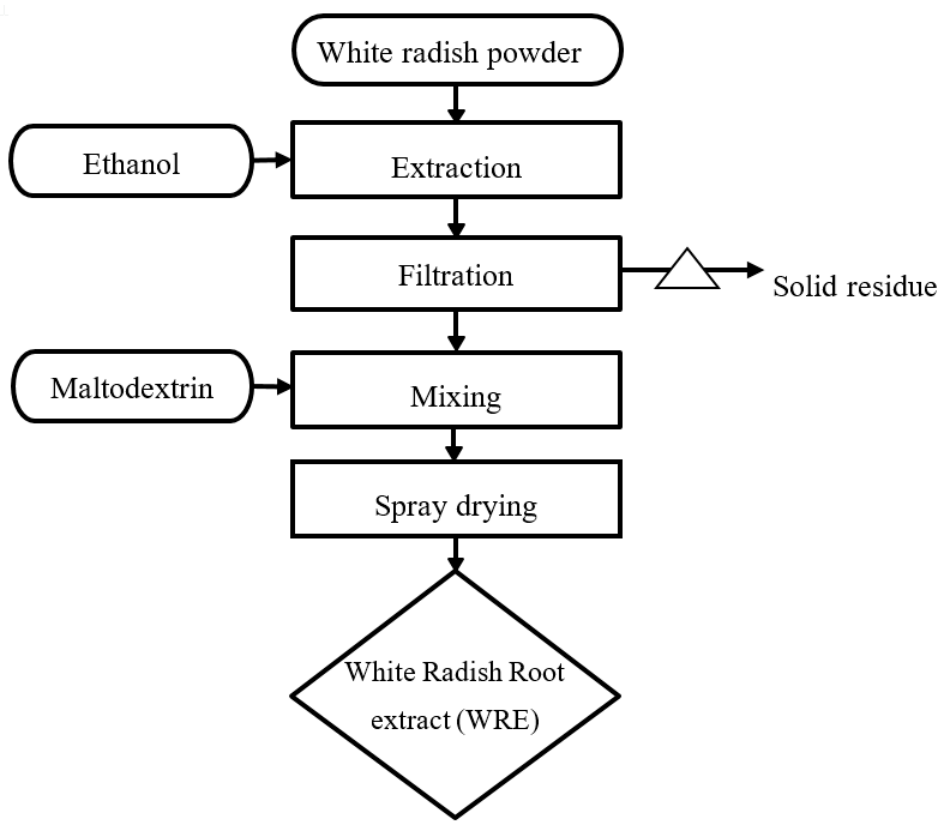

Figure 1. The procedure for the preparation of White Radish Extract (WRE).

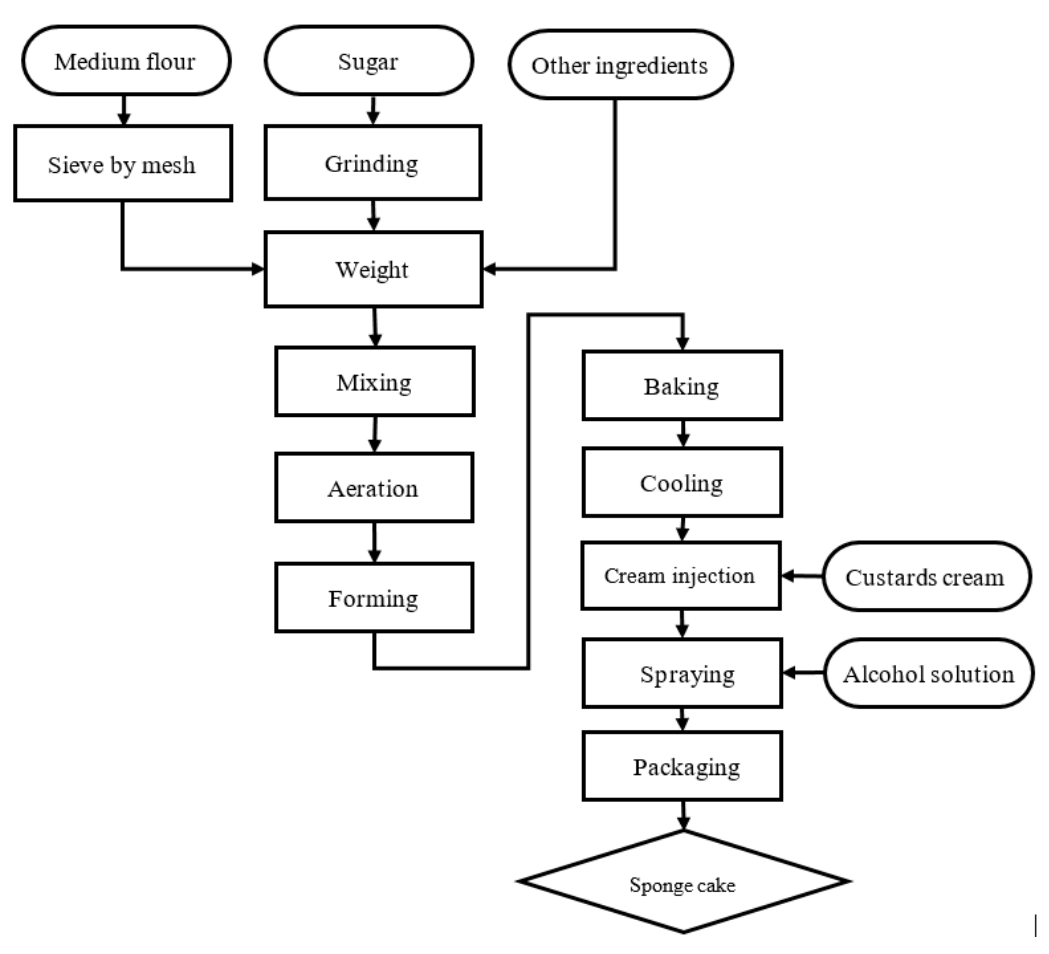

Figure 2. The procedure for preparation of sponge cake. 


\subsubsection{Determination of the Nutritional Components in White Radish Materials}

Moisture content, protein content, lipid total and ash total in the roots were determined respectively in accordance with TCVN 4326:2011, TCVN 4328:2007 (Kjeldahl), TCVN 4331:2001 and TCVN4327:2007.

\subsubsection{Determination of the Total Flavonoids}

The total flavonoids were determined by the aluminum chloride calorimetric method using quercetin as a standard [19]. The stock quercetin solution was prepared by dissolving $5.0 \mathrm{mg}$ of quercetin in $1.0 \mathrm{~mL}$ of methanol. The stock solution was serially diluted produce standard solutions with varying concentrations of quercetin $(5-200 \mu \mathrm{g} / \mathrm{mL})$. An amount of $0.6 \mathrm{~mL}$ of diluted standard quercetin solutions or $0.6 \mathrm{~mL}$ of WRE was separately mixed with $0.1 \mathrm{~mL}$ of $10 \%$ aluminum chloride. After mixing, the mixture was incubated for $60 \mathrm{~min}$ at room temperature. The contents of flavonoids were calculated from an absorbance of the reaction mixtures at $415 \mathrm{~nm}$ with a Varian UV-Vis spectrophotometer as in an equation below:

$$
\mathrm{TFC}=\frac{\mathrm{a} \times \mathrm{V} \times \mathrm{n} \times 10^{-3}}{\mathrm{~m}}
$$

where total flavonoid content (TFC), a, V, $\mathrm{m}$ and $\mathrm{n}$ are total flavonoid content (mg QE/g), quercetin content derived from the standard curve (ppm), total volume of solution $(\mathrm{mL})$, sample weight $(\mathrm{g})$ and dilution factor, respectively.

\subsubsection{Determination of the Antioxidant ABTS}

Radical scavenging activity (ABTS) was determined based on a reduction of ABTS radical cations by antioxidants in extracts [20]. The mixture of WRE and distilled water directly reacted with $\mathrm{K}_{2} \mathrm{~S}_{8} \mathrm{O}_{2}$ $2.45 \mathrm{Nm}$ (ratio 1:1) in the dark for 12-16 $\mathrm{h}$ at ambient temperature. Afterwards, $3 \mathrm{~mL}$ of ethanol solution was added and the mixture was allowed to stand for $6 \mathrm{~min}$. The absorbance was measured at a wavelength $734 \mathrm{~nm}$. Changes in optical density (OD) were calculated as follows.

$$
\% O D=\frac{A_{\text {sample }}}{A_{\text {control }}} \times 100
$$

A $_{\text {sample: }}$ absorbance of test sample, $A_{\text {Control: }}$ absorbance of blank.

ABTS radical scavenging activity was calculated as:

$$
\operatorname{ABTS}(\mathrm{mgTEAC} / \mathrm{g})=\frac{\mathrm{a} \times \mathrm{V} \times \mathrm{n} \times 250.29 \times 10^{-6}}{\mathrm{M}}
$$

a: Trolox content $(\mu \mathrm{M})$ calculated from the calibration curve. V: Total volume from solution extract (mL), M: Dry matter mass (g), n: Dilution factor, 250.29: Trolox molecular weight.

\subsubsection{Preparation of Inoculum}

Stock inoculum suspensions were prepared as described in the NCCLS M38-P document [21]. Suspensions were collected from 7-day-old cultures grown on potato dextrose agar slants and adjusted spectrophotometrically to optical densities ranging from 0.09 to 0.3 ( 82 to $60 \%$ transmittance). The stock suspensions consisted of mostly conidia and were diluted at the ratio of 1:50 in the mold medium. The final conidium counts in tested stock inoculum suspensions ranged from $0.5 \times 10^{6}$ to $4.5 \times 10^{6} \mathrm{CFU} / \mathrm{mL}$ (1000 to $9000 \mathrm{CFU}$ per the inoculated well) [22].

\subsubsection{Antifungal Susceptibility Testing by Disk Diffusion Method}

The employed microdilution methods were adapted from a described method [21]. In brief, the stock suspension of each fungal species was inoculated onto a petri disc with six wells with varying concentrations of fungi. The result was record after $48 \mathrm{~h}$ in incubator at $35^{\circ} \mathrm{C}$ as diameter 
of the inhibition zone corresponding to Aspergillus flavus, Aspergillus clavatus, Aspergillus niger, and Fusarium solani.

\subsubsection{Determination of Minimal Fungicidal Concentration (MFC)}

The in vitro minimum fungicidal concentration (MFC) was defined as the lowest drug concentration at which colonies were completely inhibited (approximately 99 to $99.5 \%$ killing activity) [22]. For each fungal species, a 7-well petri disc filled with WRE at varying concentrations from $2.5-50 \mathrm{mg} / \mathrm{mL}$ was compared with a similarly inoculated control disc filled with natamycin with concentration ranging from $0.025-0.8 \mathrm{mg} / \mathrm{mL}$. The plates were incubated at $35^{\circ} \mathrm{C}$ and the results were recorded after fungal growth was seen in the disc.

\subsubsection{Water Activity Method}

Absolute humidity is the measured amount of water in grams per cubic meter of air. Relative humidity is the amount of moisture in the air compared to the maximum amount of moisture the air contains at a given temperature. It is measured as a percentage of saturation. Theoretically foods can have a water activity between 0 (bone dry) to 1 (dry water). In this study, using the water activity meter of Aqua Lab Pre at $20^{\circ} \mathrm{C}$. Water activity is defined in the following formula: $\mathrm{a}_{\mathrm{w}}=p / p_{0}=\mathrm{ERH} / 100$ where ERH stands for equilibrium relative humidity (\%).

\subsubsection{Sensory Evaluation Method}

The employed sensory evaluation was in accordance with difference from control (DFC) method [23]. To be specific, 18 panelists were recruited and each panelist is presented with the control sponge cake product and several other batches coded with three-digit numbers. The panelist assessed the control product first and was then asked to determine how different each individual sample was when comparing with the control on a numerical scale from 1 to 6 . Of which, the scale of 1 indicated no difference and 6 was a marked difference observed between the control cake and treated cake [24].

Accepted:

6-Identical to the reference cake

5-Slight difference was observed

4-Moderately different

3-Distinctly different, but acceptable.

Rejected:

2-Distinctly different (partial or complete loss of aroma of the cake)

1-Extremely different, not consumable and considered spoiled.

\subsubsection{Texture Analysis Method}

Measurement of the firmness of sponge cake by Stable Micro Systems with texture analysis setting is pre-test speed: $2.0 \mathrm{~mm} / \mathrm{s}$, test speed: $1.0 \mathrm{~mm} / \mathrm{s}$, post-test speed: $10.0 \mathrm{~mm} / \mathrm{s}$ and distance: $8 \mathrm{~mm}$, time: $30 \mathrm{~s}$, trigger type: auto $5 \mathrm{~g}$. Accessory: AACC $36 \mathrm{~mm}$ cylinder probe with radius (P/36R) using $5 \mathrm{~kg}$ load cell.

\subsubsection{Statistical Analysis}

All experiments were performed in triplicate. The results were presented as mean \pm S.D. and subject to Duncan test. P-values of less than 0.05 were considered statistically significant. The analysis was performed using SPSS statistics 22. 


\section{Results and Discussion}

\subsection{Proximate Composition of Fresh White Radish (Raphanus sativus L.) Roots}

Proximate composition of fresh white radish roots is summarized in Table 1. The moisture content of white radish roots collected reached $96.1 \%$ and total dry mass content was $3.1 \%$ including $0.73 \%$ of protein and $2.67 \%$ of carbohydrate. Based on those results, the protein content and carbohydrate per dry matter in the material are calculated at $25.54 \%$ and $86.12 \%$, respectively.

Table 1. Composition of the fresh white radish.

\begin{tabular}{cccccc}
\hline Composition & Moisture & Protein & Lipid & Carbohydrate & Total Ash \\
\hline Content $(\%)$ & $96.1 \pm 1.35$ & $0.73 \pm 0.12$ & $<0.1$ & $2.67 \pm 0.16$ & $0.46 \pm 0.27$ \\
\hline
\end{tabular}

\subsection{Single Factor Analysis for the Extraction of WRE Using Ethanol as the Solvent}

Figure 3 visualized total flavonoid content and Trolox equivalent antioxidant capacity (TEAC) of WRE with relation to different experimental parameters. It was indicated in the Figure 3 that both TEAC and TFC content peaked at the ethanol concentration of $75 \%$ and decreased thereafter. In the ethanol concentration range from 0 to $75 \%$, the increasing trend of TFC could be attributed to the improved mass diffusivity of the materials to the media. To be specific, due to the higher polarity of the ethanol in comparison to the water, hydrogen-bonding of flavonoids with ethanol is better promoted by ethanol molecules [25]. This leads to improved dragging of flavonoids into media. On the other hands, excessively high ethanol concentration causes the solution to evaporate rapidly over time, overturning the said diffusivity improvement and in turn lowering the TFC.

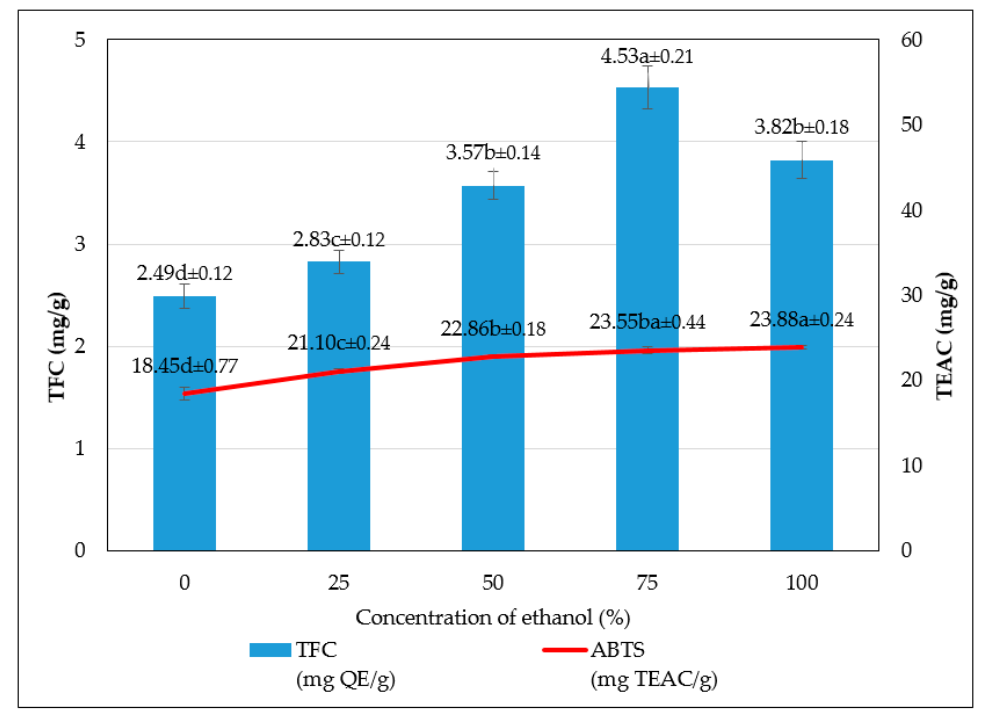

Figure 3. The effect of ethanol concentration on the total flavonoid content (TFC) and Trolox equivalent antioxidant capacity (TEAC) on WRE.

In the results of the next experiment (Figure 4), conducted at ethanol concentration $75 \%$, it was found that at the material/solvent ratio of 1:50, the TEAC and TFC peaked at 25.1 and $5.2 \mathrm{mg} / \mathrm{g}$, respectively. However, closer examinations of test statistics and the data revealed that these peak figures were statistically indifferent to those observed at the ratio of 1:30. In addition, the process performed at the high material/solvent ratio showed no economic advantages. The explanation for the relationship could be three-fold. First, the phenomenon could be due to the enlarged contact area between the materials and the extraction solvent, leading to increased extraction efficiency. Second, 
the gradient in concentration between solid and the solvent might have accelerated the mass transfer, improving the flavonoid yield [26]. Third, the material/solvent ratio could alter the equilibrium constant of the reaction and the recovery efficiency, however only to a certain threshold where the rate of yield starts to diminish with increasing ratio [27].

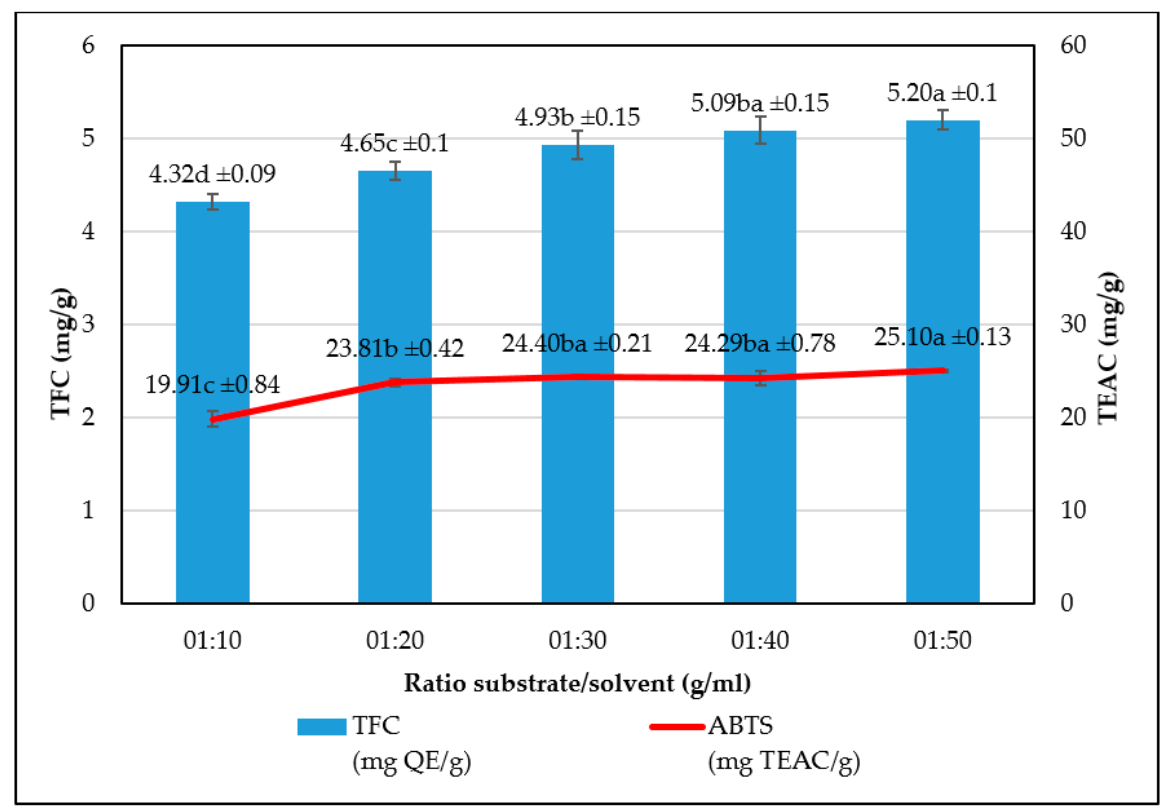

Figure 4. The effect of ratio substrate/solvent to extraction process.

The effect of temperature on the flavonoid yield and antioxidant activity of the WRE was described in the Figure 5. Experiments were performed at ethanol concentration of $75 \%$ and material/solvent ratio of 1:30. As the temperature rose from 45 to $50^{\circ} \mathrm{C}$, both TEAC and TFC witnessed a sharp rise to highest levels, at 28.26 and $6.25 \mathrm{mg} / \mathrm{g}$, respectively. Afterwards, elevating the temperature seemed to gradually reduce both indicators. Since the high temperature could reduce viscosity of the solution, physical processes that involve diffusive and convective transport of nutrients could be facilitated. Furthermore, elevated temperature of the solution may play an important part in breaking down plant cell walls and linkages inside the material such as protein-phenol or phenol-polysaccharide links. Both explanations lead to increased TEAC and flavonoid content. However, excessively high temperature could adversely affect the flavonoid and other nutrients through decomposition or combination with others component, partially contributing to their change in oxidation properties.

Extraction time and its corresponding flavonoid yield and TEAC is shown in the Figure 6. At duration of 3 and $3.5 \mathrm{~h}$, the highest level in TFC and TEAC was achieved. However, $3 \mathrm{~h}$ was selected as this duration is economical. In addition, yields obtained at prolonged periods, such as 3.5 and $4 \mathrm{~h}$, showed no clear difference in comparison to yield at $3 \mathrm{~h}$. The threshold could be explained by the Fick's second law of diffusion asserting that the equilibrium concentration of solute can be only achieved after a short period of time and short extraction time will not guarantee the extraction efficiency of antioxidant compounds [28]. Therefore, the final set of experimental parameters consisted of extraction temperature of $50^{\circ} \mathrm{C}$, the time of $3 \mathrm{~h}$, the ratio $1: 30$ and ethanol concentration of $75 \%$. These conditions correspond to the TFC content of $6.25 \pm 0.1(\mathrm{mg} / \mathrm{g})$ and TEAC of $28.95 \pm 0.43(\mathrm{mg} / \mathrm{g})$. 


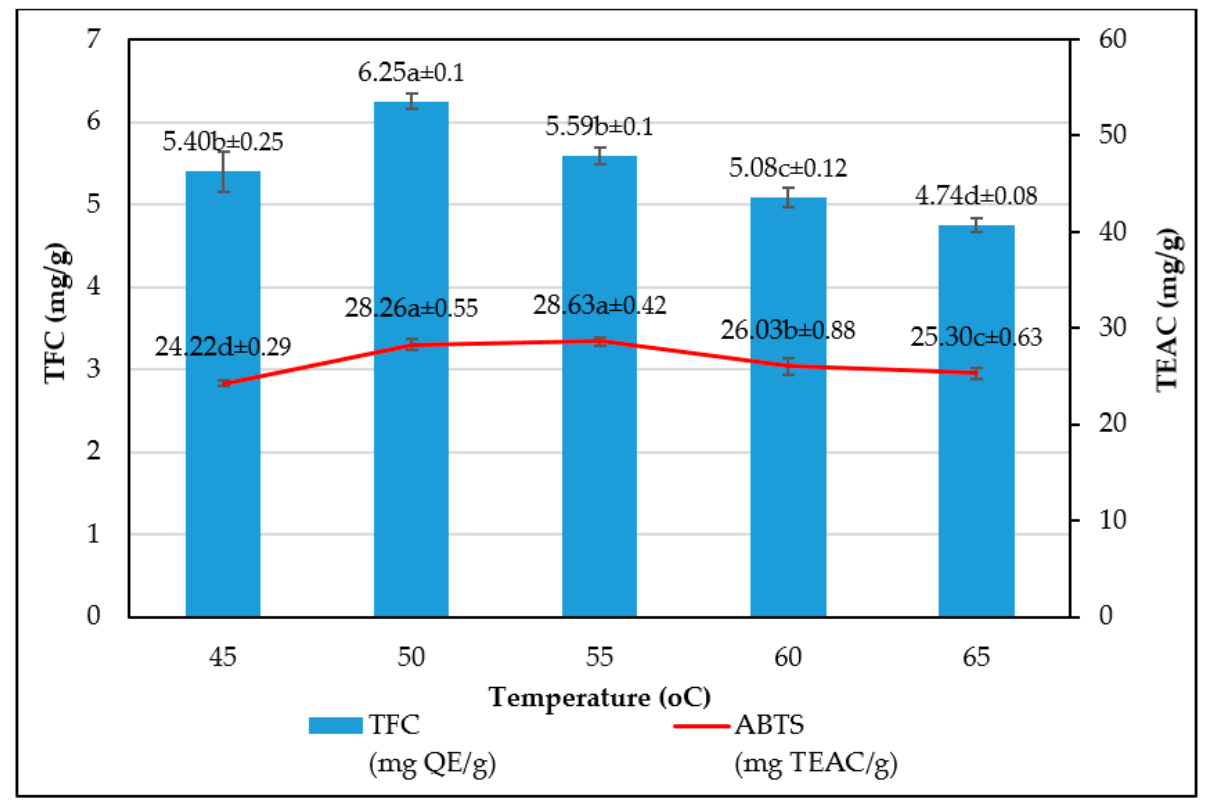

Figure 5. The effect of temperature to extraction process.

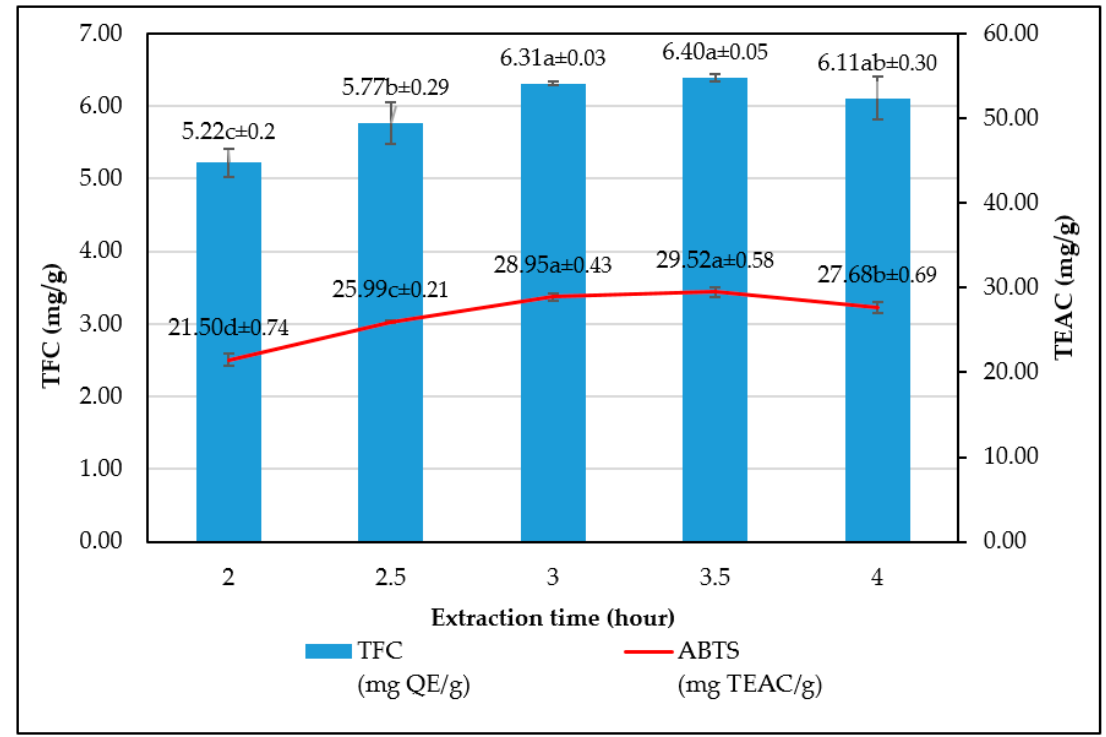

Figure 6. The effect of extraction time to extraction process.

\subsection{Antifungal Susceptibility Testing by Disk Diffusion}

Figure 7 shows the inhibition zones of various wells filled with WRE at different concentrations and with the positive control of $0.2 \mathrm{mg} / \mathrm{mL}$ natamycin. It was shown that the antifungal capacity of WRE against the four fungus species was negligible at the low concentration of $25 \mathrm{mg} / \mathrm{mL}$. At this concentration, among four species, the largest diameter was observed in the disc inoculated with Aspergillus niger, at $\mathrm{d}=10.22 \pm 1.17 \mathrm{~mm}$. Among four selected WRE concentrations, the concentration of $75 \mathrm{mg} / \mathrm{mL}$ showed the highest inhibitory effect against four species, of which the largest zone is observed against Aspergillus niger with $\mathrm{d}=19.55 \pm 1.68 \mathrm{~mm}$. Apparently, the WRE ineffectively inhibited the growth of Aspergillus flavus, as demonstrated by very low diameters of well 1 to 5 in the Aspergillus flavus disc. In summary, we found that WRE exhibited fungicidal activities against most of the fungal species, especially Aspergillus niger, and that the WRE concentration of $75 \mathrm{mg} / \mathrm{mL}$ showed superior inhibitory effects to other concentrations and even to the positive control. 


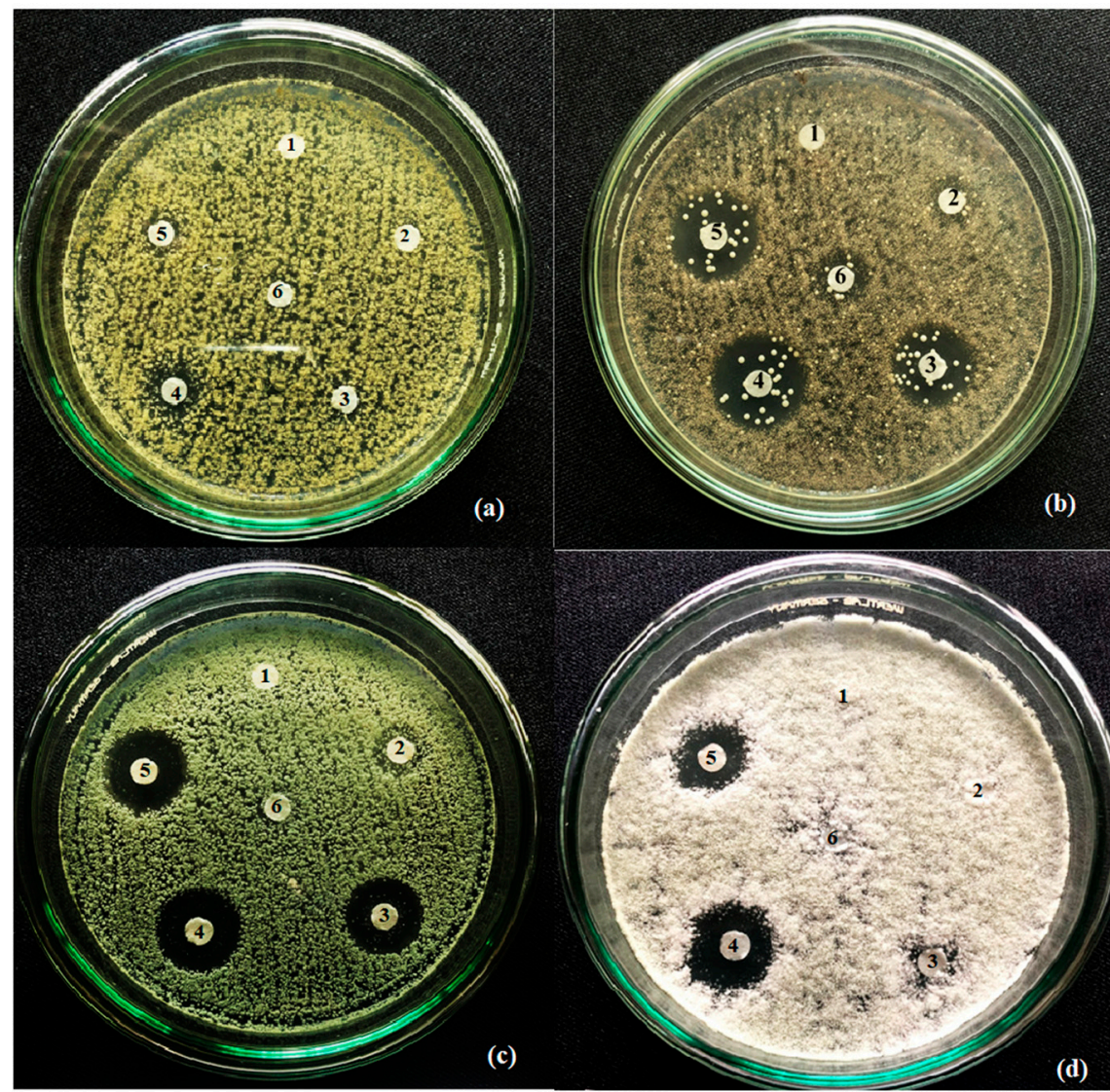

Figure 7. Antifungal susceptibility testing against (a) Aspergillus flavus NBRC 33021; (b) Aspergillus niger NBRC 4066; (c) Aspergillus clavatus NBRC 33020; (d) Fusarium solani NBRC 31094; (1): Negative control-DMSO 5\%; (2): WRE $25 \mathrm{mg} / \mathrm{mL}$; (3): WRE $50 \mathrm{mg} / \mathrm{mL}$; (4): WRE concentrate $75 \mathrm{mg} / \mathrm{mL}$; (5): WRE $100 \mathrm{mg} / \mathrm{mL}$; (6): Positive control—natamycin $0.2 \mathrm{mg} / \mathrm{mL}$.

\subsection{Minimal Fungicidal Concentration (MFC)}

Minimal fungicidal concentration (MFC) is defined as the lowest concentration of an antimicrobial agent that causes a specified reduction the visible growth of a microorganism in an agar or broth dilution susceptibility test. To determine MFC, various WRE concentrations of lower than $75 \mathrm{mg} / \mathrm{mL}$ were investigated against four fungal species and the results were compared with those of the natamycin in separate discs. The comparison is shown in Figure 8, showing a positively proportional correlation between concentration and inhibition. Table 2 details the growth of fungal colonies with respect to WRE and natamycin concentration. It was observed that at the WRE concentration of $30 \mathrm{mg} / \mathrm{mL}$, all four species were inhibited and Aspergillus niger was the most susceptible species to antifungal agents, followed by Aspergillus clavatus. The minimum MFC value of natamycin was recorded at $0.2 \mathrm{mg} / \mathrm{mL}$ for Aspergillus niger (Table 3). In general, the lowest natamycin concentration where no growth was observed after $72 \mathrm{~h}$ of incubation was lower than that of WRE concentration. Our result was similar to the recent findings of Salvosa et al. who reported that Aspergillus flavus showed no growth when treated with natamycin with concentrations ranging from $150-40000 \mu \mathrm{g} / \mathrm{mL}$, which was higher than MFC for Fusarium solani $(10 \mu \mathrm{g} / \mathrm{mL})$ [29]. 

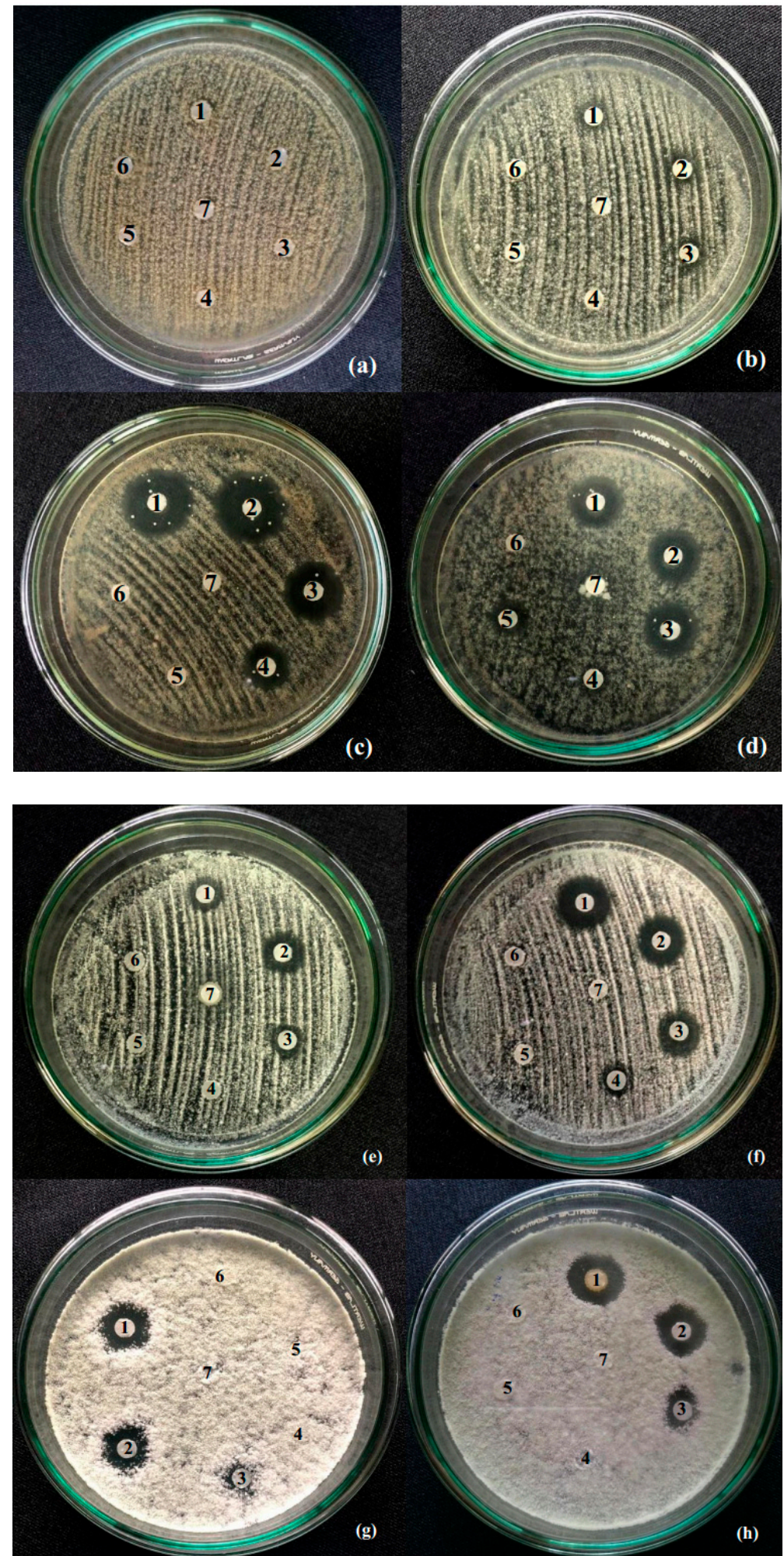

Figure 8. Minimum fungal concentration (MFC) of $(\mathbf{a}, \mathbf{b})$ : Aspergillus flavus NBRC 33021; $(\mathbf{c}+\mathbf{d})$ : Aspergillus niger NBRC 4066; (e+f): Aspergillus clavatus NBRC 33020; $(\mathbf{g}+\mathbf{h})$ : Fusarium solani NBRC 31094; disk (a,c,e,g): Natamycin and disk (b,d,f,h): WRE. 
Table 2. Inhibition zone diameter (mm) for molds of white radish extract (WRE) $\left.{ }^{*}\right)$.

\begin{tabular}{ccccc}
\hline & \multicolumn{4}{c}{ Inhibition Zone Diameter (mm) } \\
\cline { 2 - 5 } Concentration & $\begin{array}{c}\text { Aspergillus flavus } \\
\text { NBRC 33021 }\end{array}$ & $\begin{array}{c}\text { Aspergillus niger } \\
\text { NBRC 4066 }\end{array}$ & $\begin{array}{c}\text { Aspergillus clavatus } \\
\text { NBRC 33020 }\end{array}$ & $\begin{array}{c}\text { Fusarium solani } \\
\text { NBRC 31094 }\end{array}$ \\
\hline DMSO $5 \%(v / v)$ & NI & NI & NI & NI \\
WRE $55 \mathrm{mg} / \mathrm{mL}$ & $\mathrm{NI}$ & $10.22^{\mathrm{b}} \pm 1.17$ & $8.22^{\mathrm{b}} \pm 0.39$ & $6.00^{\mathrm{a}} \pm 0.00$ \\
WRE $50 \mathrm{mg} / \mathrm{mL}$ & $6.22^{\mathrm{a}} \pm 0.39$ & $17.89^{\mathrm{bc}} \pm 1.39$ & $15.34^{\mathrm{c}} \pm 0.58$ & $6.61^{\mathrm{a}} \pm 0.25$ \\
WRE $75 \mathrm{mg} / \mathrm{mL}$ & $9.11^{\mathrm{b}} \pm 1.5$ & $19.55^{\mathrm{c}} \pm 1.68$ & $17.72^{\mathrm{c}} \pm 0.25$ & $17.50^{\mathrm{b}} \pm 0.73$ \\
WRE $100 \mathrm{mg} / \mathrm{mL}$ & $7.00^{\mathrm{a}} \pm 0.67$ & $19.11^{\mathrm{c}} \pm 0.77$ & $17.66^{\mathrm{c}} \pm 0.58$ & $14.83^{\mathrm{b}} \pm 0.60$ \\
Natamycin $0.2 \mathrm{mg} / \mathrm{mL}$ & $6.33^{\mathrm{a}} \pm 0.58$ & $11.5^{\mathrm{b}} \pm 1.02$ & $6.22^{\mathrm{a}} \pm 0.39$ & $6.00^{\mathrm{a}} \pm 0.00$ \\
\hline
\end{tabular}

$\left({ }^{*}\right)$ mean value \pm SD of triplicate experiments, $n=3$ (the zone of inhibition $\mathrm{mm}$ including a disk of $6 \mathrm{~mm}$ in diameter). $\mathrm{NI}=$ no inhibition .

Table 3. MFC values of WRE and natamycin against the four species.

\begin{tabular}{cccccccccccccccccc}
\hline \multirow{2}{*}{ Species } & \multicolumn{1}{c}{ Concentration of WRE $(\mathrm{mg} / \mathrm{mL})$} & \multicolumn{1}{c}{ Concentration of Natamycin $(\mathrm{mg} / \mathrm{mL})$} \\
\cline { 2 - 13 } & $\mathbf{5 0}$ & $\mathbf{4 0}$ & $\mathbf{3 0}$ & $\mathbf{2 0}$ & $\mathbf{1 0}$ & $\mathbf{5}$ & $\mathbf{2 . 5}$ & $\mathbf{0 . 8}$ & $\mathbf{0 . 6}$ & $\mathbf{0 . 4}$ & $\mathbf{0 . 2}$ & $\mathbf{0 . 1}$ & $\mathbf{0 . 0 5}$ & $\mathbf{0 . 0 2 5}$ \\
\hline Aspergillus flavus NBRC 33021 & + & + & + & - & - & - & - & + & + & + & - & - & - & - \\
\hline Aspergillus niger NBRC 4066 & + & + & + & + & + & - & - & + & + & + & + & - & - & - \\
\hline Aspergillus clavatus NBRC 33020 & + & + & + & + & - & - & - & + & + & + & - & - & - & - \\
\hline Fusarium solani NBRC 31094 & + & + & + & - & - & - & - & + & + & + & - & - & - & - \\
\hline
\end{tabular}

(+) No growth, (-) Growth.

\subsection{Shelf-Life Study of Sponge Cake in Air-Cooled Condition $20^{\circ} \mathrm{C}$}

\subsubsection{Water Activity}

Water activity, unlike water content, can determine shelf stability of foods since the development potential of spoilage-causing microorganisms could be predicted based on the water activity. The water activity of a food is also instrumental in maintaining its chemical stability [30]. Therefore, food products can be safely produced and preserved by lowering water activity to the point that microorganisms cannot grow. Figure 9 illustrates water activity measurements (Aw) of sponge cake added with WRE and sponge cake added with potassium sorbate with relation to different storage periods at $20^{\circ} \mathrm{C}$. Overall, both cake samples exhibited similar water activity ranging from $0.65-0.71$ and the trend was gradually increasing over the examined course.

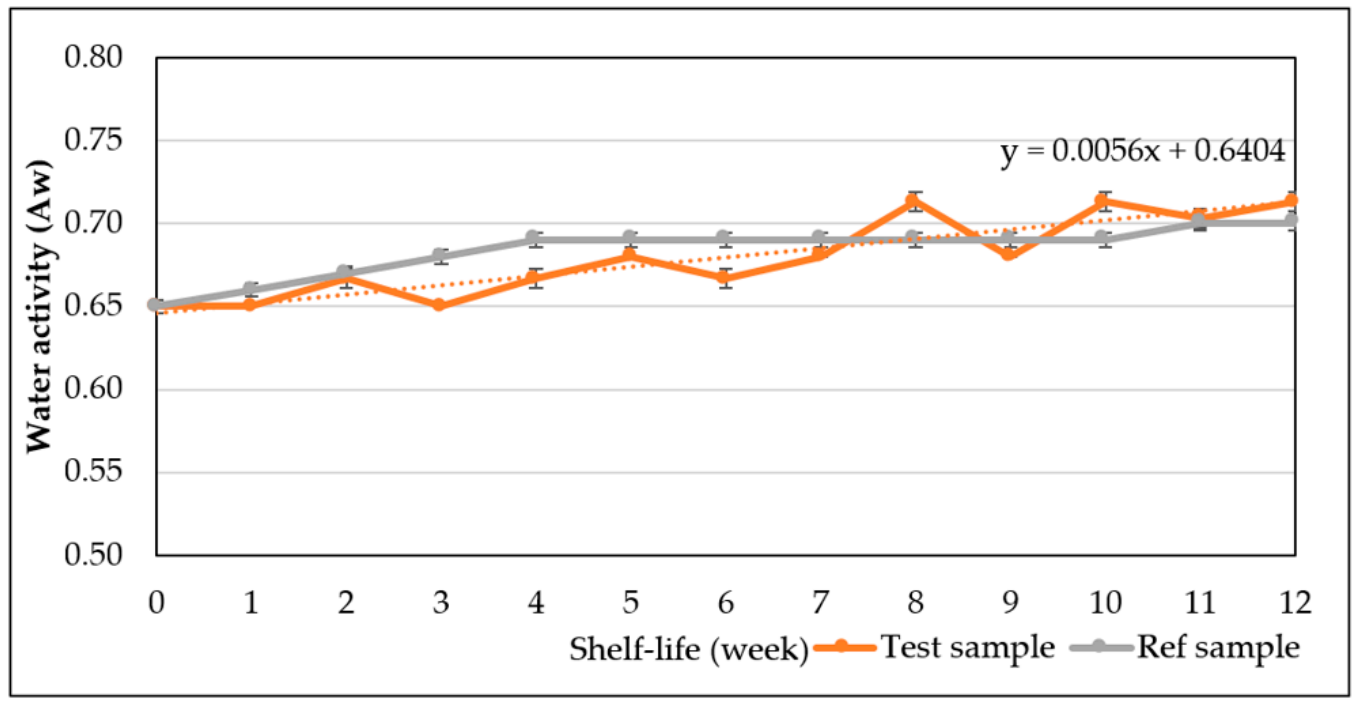

Figure 9. Water activity at $20^{\circ} \mathrm{C}$ after various storage periods. 


\subsubsection{Sensory Evaluation}

Overall, the sensory evaluation (SE) score of panelists gradually decreased from 6, evaluated with initial cakes, to 3.08, evaluated at cakes after 12 weeks of storage (Figure 10). These figures indicated that the quality of sponge cake added with WRE was acceptable even after 12 weeks of storage under $20^{\circ} \mathrm{C}$.

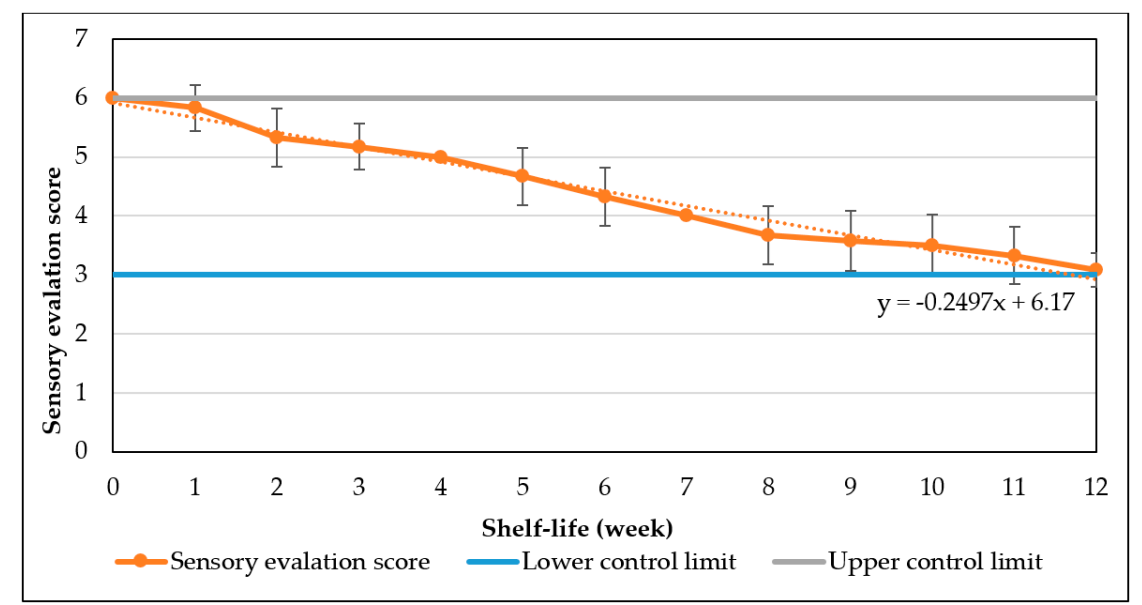

Figure 10. Sensory evaluation score in air-cooled condition $20^{\circ} \mathrm{C}$ after various storage times.

\subsubsection{Texture Analysis}

Firmness of sponge cakes after various storage times are visualized on Figure 11 and in Table 4. Maximum firmness of sponge cake was reached at the 11 th week $(732.08 \pm 3.37)$. In cakes after 12 weeks of storage, the texture was slightly softer $(578.15 \pm 0.07)$. In comparison with the standard sample (sponge cake stored at $5{ }^{\circ} \mathrm{C}$ ), the surface of the cake was drier. The explanation could be due to the natural starch degradation occurring in the sample. For this reason, it was suggested that application of WRE $30 \mathrm{mg} / \mathrm{mL}$ did not improve texture of sponge cake.

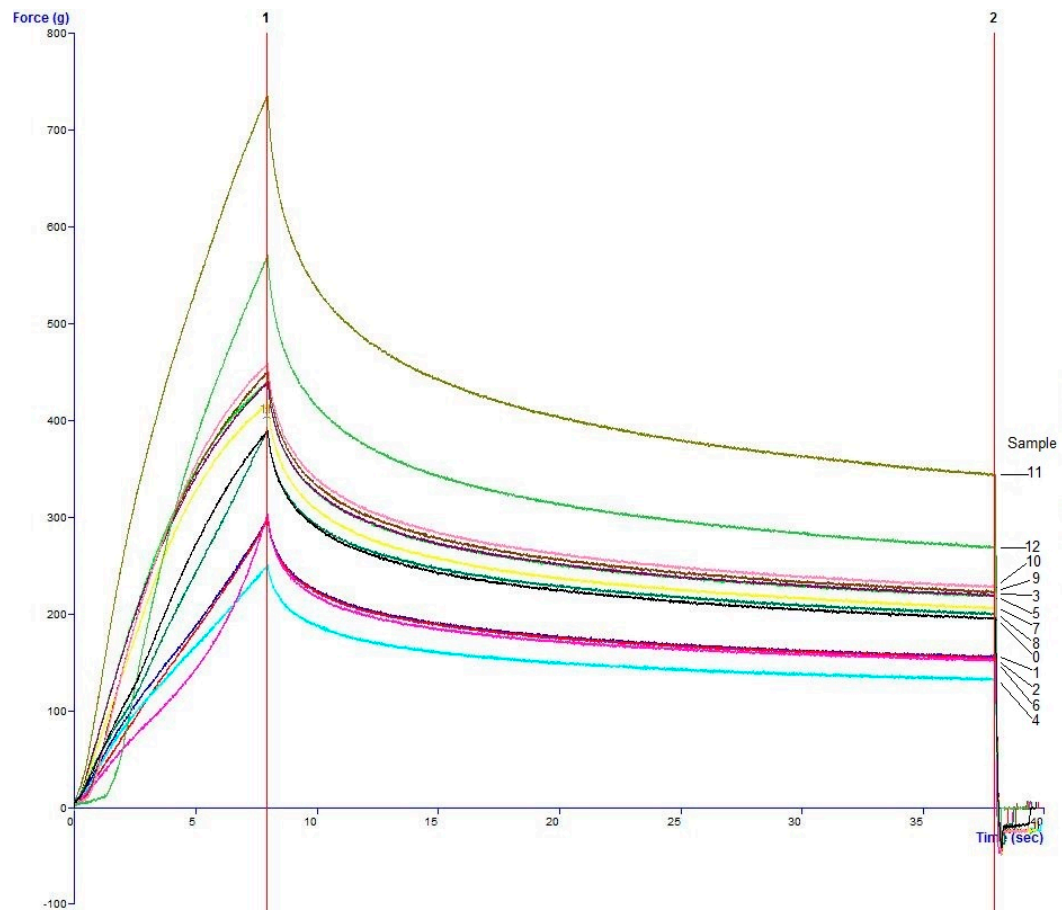

Figure 11. Firmness of sponge cakes in air-cooled condition $20^{\circ} \mathrm{C}$ and after various storage times. 
Table 4. Firmness of sponge cakes in air-cooled condition.

\begin{tabular}{|c|c|c|c|c|c|c|c|}
\hline Time (Week) & 0 & 1 & 2 & 3 & 4 & 5 & 6 \\
\hline $\begin{array}{l}\text { Average Firmness } \\
\text { (F) }\end{array}$ & $\begin{array}{c}370.23^{\mathrm{a}} \pm \\
15.03\end{array}$ & $\begin{array}{c}450.06^{\mathrm{b}} \pm \\
30.74\end{array}$ & $\begin{array}{c}419.96^{\mathrm{b}} \pm \\
19.49\end{array}$ & $\begin{array}{c}355.64^{\mathrm{a}} \pm \\
10.80\end{array}$ & $\begin{array}{c}312.23^{c} \pm \\
19.49^{-}\end{array}$ & $\begin{array}{c}445.19^{\mathrm{b}} \pm \\
4.24\end{array}$ & $\begin{array}{c}295.36^{c} \pm \\
26.79\end{array}$ \\
\hline Time (Week) & 7 & 8 & 9 & 10 & 11 & 12 & \\
\hline $\begin{array}{l}\text { Average Firmness } \\
\text { (F) }\end{array}$ & $\begin{array}{c}335.39^{a} \pm \\
8.72\end{array}$ & $\begin{array}{l}394.70^{\mathrm{a}} \pm \\
33.42\end{array}$ & $\begin{array}{c}455.97^{b} \pm \\
19.34\end{array}$ & $\begin{array}{c}462.47^{b} \pm \\
2.14\end{array}$ & $\begin{array}{c}732.08^{\mathrm{d}} \pm \\
3.37\end{array}$ & $\begin{array}{c}578.15^{\mathrm{e}} \pm \\
0.07\end{array}$ & \\
\hline
\end{tabular}

Means with different superscripts in the same column are significantly different at $p<0.05$ by Duncan's multiple range test.

\subsubsection{Microbiological Indication}

Sponge cake added WRE was evaluated for various microbiological indicators after various storage periods. The results are presented in the Table 5.

Table 5. Microbiological testing results of sponge cake after storage time.

\begin{tabular}{cccccccc}
\hline Microorganisms & Unit & $\begin{array}{c}\text { Permissible } \\
\text { Range }\left(^{*}\right)\end{array}$ & $\begin{array}{c}\text { 4th } \\
\text { Week }\end{array}$ & $\begin{array}{c}\text { 8th } \\
\text { Week }\end{array}$ & $\begin{array}{c}\text { 12nd } \\
\text { Week }\end{array}$ & $\begin{array}{c}\text { 12nd Week } \\
\text { (Control) }\end{array}$ & Method $\left(^{* *}\right)$ \\
\hline $\begin{array}{c}\text { Bacillus cereus } \\
\text { Clostridium perfringens }\end{array}$ & Cfu/g & $<10$ & ND & ND & ND & ND & AOAC 980.31 \\
Coliforms & Cfu/g & $<10$ & ND & ND & ND & ND & ISO 7937:2004 \\
$\begin{array}{c}\text { E. coli } \\
\text { Cfu/g }\end{array}$ & 3 & ND & ND & ND & ND & ISO 4832:2006 \\
Staphylococcus aureus & Cfu/g & $<10$ & ND & ND & ND & ND & ISO 16649-2:2001 \\
$\begin{array}{c}\text { Molds and yeasts } \\
\text { Total aerobic }\end{array}$ & Cfu/g & $10^{2}$ & $10^{2}$ & $10^{3}$ & $2 \times 10^{3}$ & 10 & ISO 6888-1:2003 \\
microbial count & Cfu/g & $10^{4}$ & $10^{4}$ & $2 \times 10^{4}$ & $3 \times 10^{4}$ & $10^{2}$ & ISO 4833-1:1013 \\
\hline
\end{tabular}

$\left(^{*}\right)$ In accordance to the decision No.46/2007/QD-BYT of the Ministry of Health, Vietnam on promulgation regulation of maximum level of biological and chemical pollution in food. $\left({ }^{* *}\right)$ LOD of method $=10 \mathrm{cfu} / \mathrm{g}$. ND-Not detected. The control was sponge cake that added with potassium sorbate and stored at $20^{\circ} \mathrm{C}$ for 11 weeks.

After 8 weeks stored at air-cooled condition $20^{\circ} \mathrm{C}$, the sponge cake added with WRE showed higher total aerobic microbial count, molds and yeasts than the standard requirement. Based on the results, the storage time of sponge cake added with WRE is approximately 8 weeks at air-cooled condition of $20^{\circ} \mathrm{C}$.

\subsection{Shelf-Life Study of Sponge Cake in Accelerated Condition $37^{\circ} \mathrm{C}$}

\subsubsection{Water Activity}

Figure 12 shows the range of water activity of sponge cake at different storage periods. Overall, water activity ranged from 0.65 to 0.71 , demonstrating that sponge cake added with WRE can inhibit the activity of most bacteria and yeasts. In this temperature condition, one additional week of storage rises the water activity of the sponge cake by approximately 0.016 .

\subsubsection{Sensory Evaluation}

Under $37^{\circ} \mathrm{C}$, it was indicated that the sensory score fell rapidly and approximated the lower control limit of 3.00 for cake samples after 4 weeks of storage (Figure 13). This number is lower in comparison with the previous sensory results where the lower limit was reached at cake samples stored after 12 weeks. After four weeks, SE score was $3.25 \pm 0.45$ (>3, lower control limit), suggesting acceptable quality of the cake. 


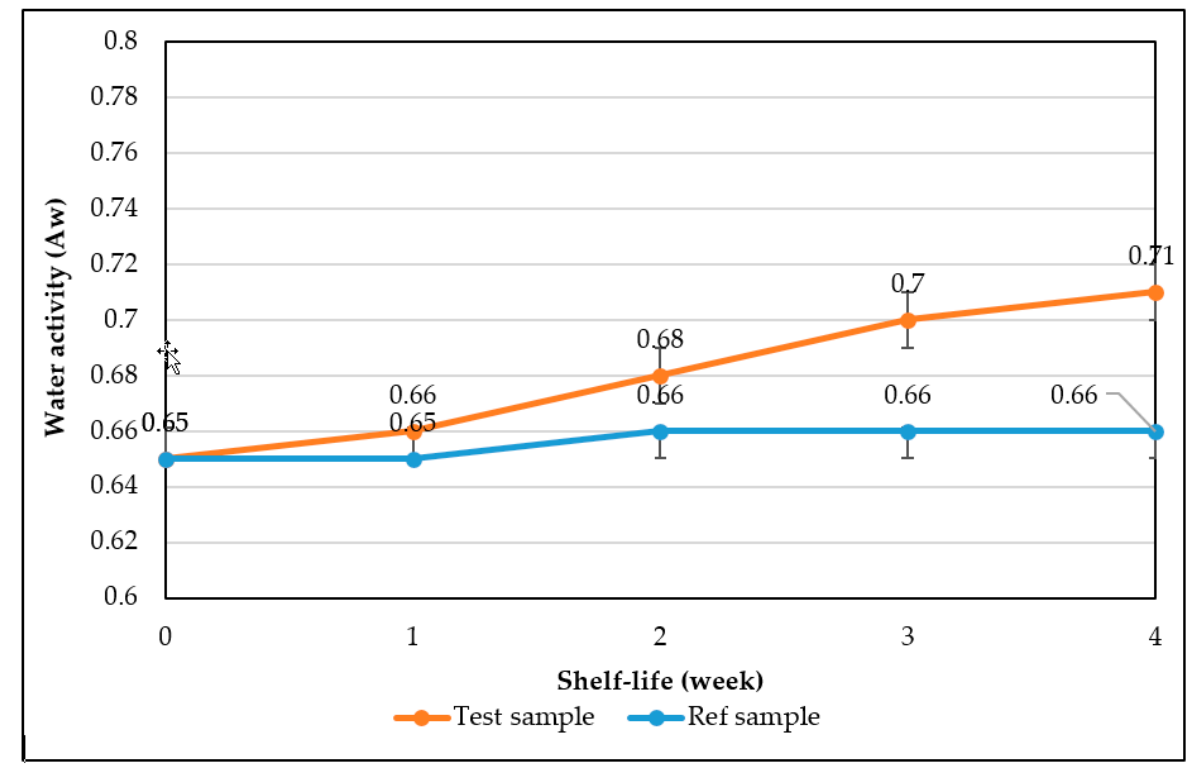

Figure 12. Water activity of sponge cake in accelerated condition $20^{\circ} \mathrm{C}$ after various storage times.

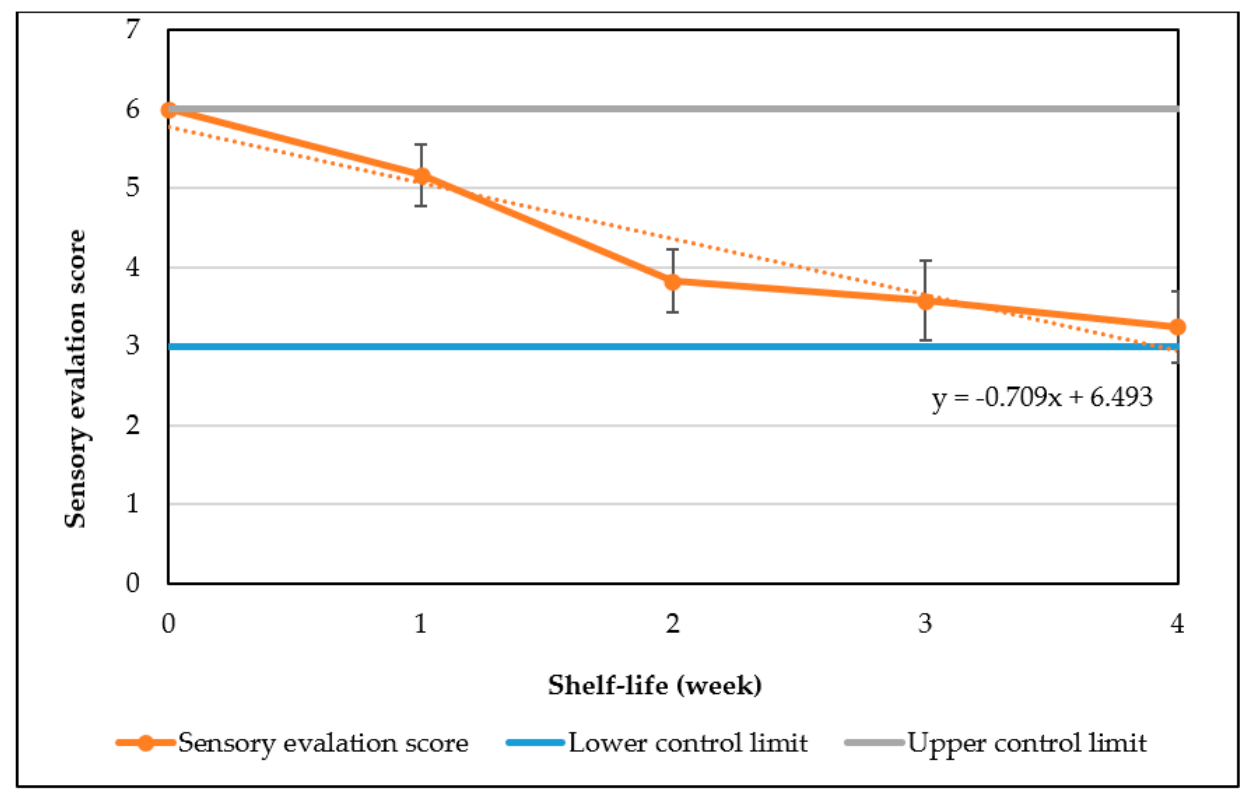

Figure 13. Sensory evaluation score in accelerated condition $37^{\circ} \mathrm{C}$.

\subsubsection{Texture Analysis}

The results for the firmness of sponge cake stored under $37^{\circ} \mathrm{C}$ are shown in the Table 6 and Figure 14. The firmness of sponge cake increased rapidly and reached the highest value at the third week $(792.53 \mathrm{~F})$ which is equivalent to the values of cakes stored in air-cooled condition after 11 weeks in the previous experiment. The accelerated texture degradation could be partially attribute to the elevated temperature [31].

Table 6. Firmness of sponge cakes in accelerated condition $37^{\circ} \mathrm{C}$.

\begin{tabular}{lccccc}
\hline Time (week) & $\mathbf{0}$ & $\mathbf{1}$ & $\mathbf{2}$ & $\mathbf{3}$ & $\mathbf{4}$ \\
\hline Average Firmness (F) & $371.89^{\mathrm{a}} \pm 13.67$ & $578.34^{\mathrm{b}} \pm 1.73$ & $525.37^{\mathrm{b}} \pm 1.98$ & $792.53^{\mathrm{c}} \pm 1.30$ & $667.56^{\mathrm{d}} \pm 1.05$ \\
\hline $\begin{array}{l}\text { Means with different superscripts in the same column are significantly different at } p<0.05 \text { by Duncan's multiple } \\
\text { range test. }\end{array}$
\end{tabular}




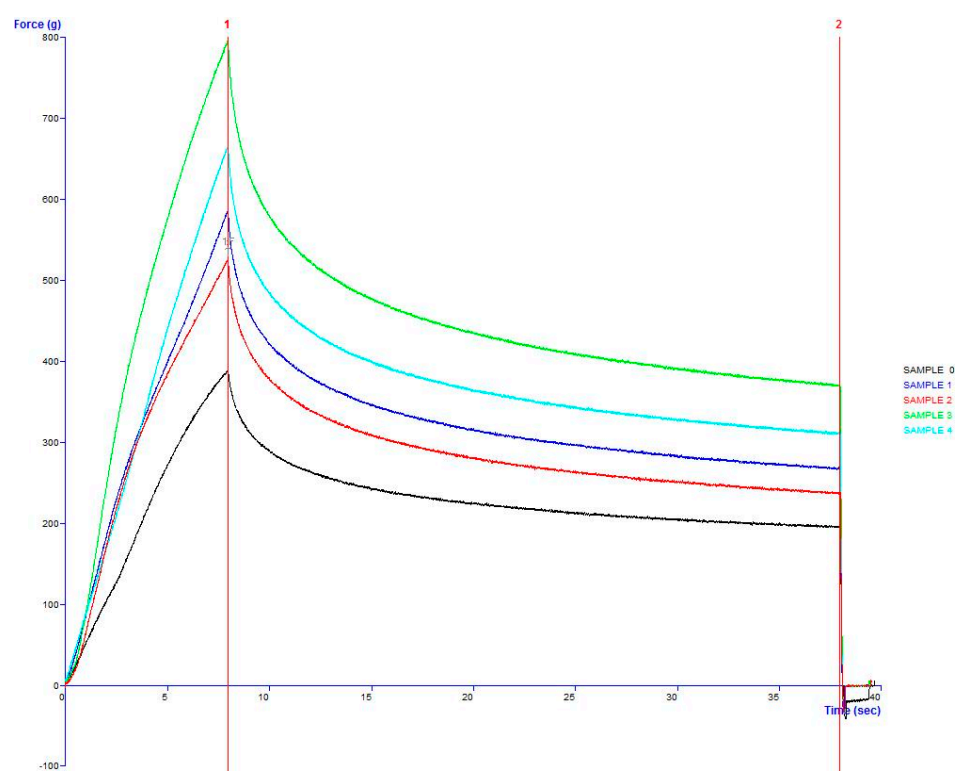

Figure 14. Firmness of sponge cakes in accelerated condition $37^{\circ} \mathrm{C}$.

\subsubsection{Microbial Testing}

Sponge cake added with WRE and stored in at $37^{\circ} \mathrm{C}$ was tested for microbial indicators. The results are shown in Table 7.

Table 7. Microbial testing results of sponge cake after different storage periods at $37^{\circ} \mathrm{C}$.

\begin{tabular}{cccccccc}
\hline Microorganisms & Unit & $\begin{array}{c}\text { Permissible } \\
\text { Range }\left(^{*}\right)\end{array}$ & $\begin{array}{c}\text { 4th } \\
\text { Week }\end{array}$ & $\begin{array}{c}\text { 8th } \\
\text { Week }\end{array}$ & $\begin{array}{c}\text { 12nd } \\
\text { Week }\end{array}$ & $\begin{array}{c}\text { 12nd Week } \\
\text { (Control) }\end{array}$ & Method $\left(^{* *}\right)$ \\
\hline Bacillus cereus & Cfu/g & $<10$ & ND & ND & ND & ND & AOAC 980.31 \\
Clostridium perfringens & Cfu/g & $<10$ & ND & ND & ND & ND & ISO 7937:2004 \\
Coliforms & Cfu/g & $<10$ & ND & ND & ND & ND & ISO 4832:2006 \\
E. coli & Cfu/g & 3 & ND & ND & ND & ND & ISO 16649-2:2001 \\
Staphylococcus aureus & Cfu/g & $<10$ & ND & ND & ND & ND & ISO 6888-1:2003 \\
$\begin{array}{c}\text { Molds and yeasts } \\
\text { Total aerobic }\end{array}$ & Cfu/g & $10^{2}$ & ND & $2 \times 10^{3}$ & $10^{4}$ & 10 & ISO 21527-2:2008 \\
microbial count & Cfu/g & $10^{4}$ & $10^{3}$ & $3 \times 10^{4}$ & $4 \times 10^{4}$ & $10^{2}$ & ISO 4833-1:1013 \\
\hline
\end{tabular}

${ }^{*}$ ) In accordance with decision No.46/2007/QD-BYT of the Ministry of Health, Vietnam on promulgation regulation of maximum level of biological and chemical pollution in food. $\left.{ }^{* *}\right)$ LOD of method $=10 \mathrm{cfu} / \mathrm{g}$. ND-Not detected. The control was sponge cake that added with potassium sorbate and stored at $37^{\circ} \mathrm{C}$ for 11 weeks.

After three weeks of storage at $37^{\circ} \mathrm{C}$, the WRE-added sponge cake still maintained most of microorganism indicators below the permissible range. However, at the 8 th week, sponge cake added with WRE exceeded the permissible upper limit in terms of total number of yeasts and molds as well as the total number of aerobic microorganisms. For comparison, the control cake, which was added with potassium sorbate, exhibited excellent anti-microorganism activity with all indicators below the permissible range even after 11 weeks. Therefore, it is suggested that the WRE could only act as a anti-microorganism agent of moderate activity and sponge cake added with WRE should have the shelf-life of under 4 weeks, most preferably 2 weeks, when stored at $37^{\circ} \mathrm{C}$.

\section{Conclusions}

The study has optimized the total flavonoid content and antioxidant activity of the white radish root extract with regard to four extraction parameters including concentration of ethanol, ratio of solvent/material, temperature and time. Optimized parameters consisted of extraction temperature of $50{ }^{\circ} \mathrm{C}$, the time of $3 \mathrm{~h}$, ratio of 1:30 and ethanol concentration of $75 \%$. These conditions correspond to the TFC content of $6.25 \pm 0.1 \mathrm{mg} / \mathrm{g}$ and TEAC of $28.95 \pm 0.43 \mathrm{mg} / \mathrm{g}$. In vitro disk diffusion assay showed 
that WRE could inhibit four fungal species of Aspergillus flavus, Aspergillus niger, Aspergillus clavatus, and Fusarim solani with concentration of $75 \mathrm{mg} / \mathrm{mL}$. For Aspergillus flavus and Fusarim solani, the MIC of WRE was $30 \mathrm{mg} / \mathrm{mL}$. The figures were 20 and $10 \mathrm{mg} / \mathrm{mL}$ for Aspergillus clavatus and Aspergillus niger, respectively. To maintain acceptable physical, sensory and microbial parameters, sponge cakes added with WRE are suggested to have the shelf-life of 8 weeks at storage temperature of $20^{\circ} \mathrm{C}$ or 2 weeks at $37^{\circ} \mathrm{C}$. These results suggest the use of white radish as a potential material for manufacture of natural preservatives.

Author Contributions: Investigation, H.H.D., P.T.K.N., L.T.H.A. and V.T.T., Supervision, D.T.A.D.; Writingoriginal draft, H.H.D.; Writing-review \& editing, D.C.N.

Funding: This research received no external funding.

Acknowledgments: We are thankful to the researchers from Technology Laboratory of Faculty of Chemical Engineering, HCMC University of Technology, Vietnam National University, for their support and for providing valuable advice during this work.

Conflicts of Interest: The authors declare no conflict of interest.

\section{References}

1. Figuié, M. Vegetable Consumption Behaviour in Hanoi; CIRAD-AMIS: Hanoi, Vietnam, 2003; p. 25. Available online: http://agritrop.cirad.fr/577491/ (accessed on 1 July 2019).

2. Paredes, S.D. Etnobotánica Mexicana: Plantas popularmente empleadas en el Estado de Michocán en el tratamiento de enfermedades hepaticas y vesiculares. UNAM Pedobiol. 1984, 47, 846-856.

3. Gutiérrez, R.M.P.; Perez, R.L. Raphanus sativus (Radish): Their Chemistry and Biology. Sci. World J. 2004, 4, 811-837. [CrossRef] [PubMed]

4. Salah-Abbesa, J.B.; Abbesa, S.; Haous, Z.; Oueslati, R. Raphanus Sativus Extract Prevents and Ameliorates Zearalenone-Induced Peroxidative Hepatic Damage in Balb/c Mice. J. Pharm. Pharmacol. 2009, 61, 1545-1554. [CrossRef]

5. Beevi, S.S.; Mangamoori, L.N.; Dhand, V.; Ramakrishna, D.S. Isothiocyanate profile and selective antibacterial activity of root, stem, and leaf extracts derived from Raphanus sativus L. Foodborne Pathog. Dis. 2009, 6, 129-136. [CrossRef]

6. Beevi, S.S.; Mangamoori, L.N.; Anabrolu, N. Comparative activity against pathogenic bacteria of the root, stem, and leaf of Raphanus sativus grown in India. World J. Microb. Biot. 2009, 25, 465. [CrossRef]

7. Singh, P.; Singh, J. Medicinal and therapeutic utilities of raphanus sativus. Int. J. Plant Anim. Environ. Sci. 2013, 3, 103-105.

8. Rani, I.; Akhund, S.; Abro, H. Antimicrobial potential of seed extract of Raphanus sativus. Pak. J. Bot. 2008, 40, 1793-1798.

9. Abdou, I.A.; Abou-Zeid, A.A.; El-Sherbeeny, M.R.; Abou-El-Gheat, Z.H. Antimicrobial activities of Allium sativum, Allium cepa, Raphanus sativus, Capsicum frutescens, Eruca sativa, Allium kurrat on bacteria. Plant Food Hum. Nutr. 1972, 22, 29-35. [CrossRef]

10. Ivánovics, G.; Horváth, S. Raphanin, an Antibacterial Principle of the Radish (Raphanus sativus). Nature 1947, 160, 297-298. [CrossRef] [PubMed]

11. Kaymak, H.C.; Ozturk, S.; Ercisli, S.; Guvenc, I. In Vitro antibacterial activities of black and white radishes (Raphanus Sativus L.). Comptes Rendus de l'Académie Bulgare des Sciences Sciences Mathématiques et Naturelles 2015, 68, 201-208.

12. Shukla, S.; Chatterji, S.; Yadav, D.K.; Watal, G. Antimicrobial efficacy of raphanus sativus root juice. Int. J. Pharm. Pharm. Sci. 2011, 3, 89-92.

13. Lourenço, R.M.D.C.; Melo, P.D.S.; Almeida, A.B.A.D. Flavonoids as Antifungal Agents; Antifungal Metabolites from Plants; Springer: Berlin/Heidelberg, Germany, 2013; pp. 283-300.

14. Wink, M.; Ashour, M.L.; El-Readi, M.Z. Secondary metabolites from plants inhibiting ABC transporters and reversing resistance of cancer cells and microbes to cytotoxic and antimicrobial agents. Front. Microbiol. 2012, 3, 130-145. [CrossRef]

15. Srivastava, M.P.; Tiwari, R.; Sharma, N. Assessment of phenol and flavonoid content in the plant materials. JNBR 2013, 2, 163-166. 
16. Janjua, S. Phytochemical analysis and in vitro antibacterial activity of root peel extract of Raphanus sativus L. var niger. Adv. Med. Plant Res. 2013, 1,1-7.

17. Cao, J.; Chen, W.; Zhang, Y.; Zhang, Y.; Zhao, X. Content of Selected Flavonoids in 100 Edible Vegetables and Fruits. Food Sci. Technol. Res. 2010, 16, 395-402. [CrossRef]

18. Rodríguez-García, J.; Sahi, S.S.; Hernando, I. Optimizing mixing during the sponge cake manufacturing process. Cereal Foods World 2014, 59, 287-292. [CrossRef]

19. Kim, J.K.; Baskar, T.B.; Park, S.U. Total Phenolic and Flavonoid Contents and Antioxidant Activities of Two Raphanus sativus L. cultivars (Cherry Belle and Valentine). Biosci. Biotechnol. Res. Asia 2016, 13, 31-36. [CrossRef]

20. Alexandru, V.; Balan, M.; Gaspar, A.; Coroiu, V. Antioxidant activity, phenolics and flavonoid content of some selected Romanian medicinal plants. Planta Med. 2007, 73, 261. [CrossRef]

21. Pfaller, M.A.; Haturvedi, V.; Espinel-Ingroff, A.; Ghannoum, M.A.; Gosey, L.L.; Odds, F.C.; Warnock, D.W. Reference Method for Broth Dilution Antifungal Susceptibility Testing of Yeasts; Approved Standard Second Edition Serving the World's Medical Science Community Through Voluntary Consensus; Clinical and Laboratory Standards Institute: Wayne, PA, USA, 2002; Volume 22.

22. Espinel-Ingroff, A. In Vitro Fungicidal Activities of Voriconazole, Itraconazole, and Amphotericin B against Opportunistic Moniliaceous and Dematiaceous Fungi. J. Clin. Microbiol. 2001, 39, 954-958. [CrossRef] [PubMed]

23. Rogers, L.L. Sensory methods for quality control. In Sensory Analysis for Food and Beverage Quality Control; Kilcast, D., Ed.; Woodhead Publishing Series in Food Science, Technology and Nutrition; Woodhead Publishing: Sawston/Cambridge, UK, 2010; pp. 51-74. ISBN 9781845694760.

24. Sozer, N.; Kokini, J.L.; Bruins, R.; Dietzel, C.; Franke, W.; Trottier, B.; Harrington, S. Quality Improvement Project for Shelf Stable Bakery Products. The Center for Advanced Food Technology. Available online: https://apps.dtic.mil/dtic/tr/fulltext/u2/a528594.pdf (accessed on 1 July 2019).

25. Brouillard, R.; Dangles, O. Anthocyanin molecular interactions: The first step in the formation of new pigments during wine aging? Food Chem. 1994, 51, 365-371. [CrossRef]

26. Cacace, J.E.; Mazza, G. Mass transfer process during extraction of phenolic compounds from milled berries. J. Food Eng. 2003, 59, 379-389. [CrossRef]

27. Hamdan, S.; Daood, H.G.; Toth-Markus, M.; Illés, V. Extraction of cardamom oil by supercritical carbon dioxide and sub-critical propane. J. Supercrit. Fluids 2008, 44, 25-30. [CrossRef]

28. Fick, A. Ueber Diffusion. Ann. Der Phys. 1855, 170, 59-86. [CrossRef]

29. Salvosa, F.A.M.; Cubillan, L.P.; Nievera, L.F. In Vitro evaluation of natamycin 5\% suspension against Aspergillus flavus, Fusarium solani, and Candida parasilopsis. Philipp. J. Ophthalmol. 2004, 29, 26-28.

30. Sandulachi, E. Water Activity Concept and its Role in Food Preservation. Available online: http://81.180.74. 21/handle/5014/780 (accessed on 1 July 2019).

31. Jahan, M.G.S.; Pervin, M.S.; Rana, A.M.; Shovon, M.S.; Sharma, S.C.D.; Karim, M.R.; Rahman, M.H. Correlation between $\beta$-amylase activity and starch content in different cultivars of radish (Raphanus sativus L.). Bio Technol. Indian J. 2014, 9, 298-302.

(C) 2019 by the authors. Licensee MDPI, Basel, Switzerland. This article is an open access article distributed under the terms and conditions of the Creative Commons Attribution (CC BY) license (http://creativecommons.org/licenses/by/4.0/). 